\title{
Research on Climate Change Policies and Rural Development in Latin America: Scope and Gaps
}

\author{
Bruno Locatelli ${ }^{1,2, *}$ (D), Paulina Aldunce ${ }^{3}$, Abigaiil Fallot ${ }^{1}$ (D) , Jean-François Le Coq ${ }^{1,4}$, \\ Eric Sabourin ${ }^{1,5}$ and Jeimar Tapasco ${ }^{4}$ \\ 1 Agricultural Research for Development, CIRAD, 34398 Montpellier, France; abigail.fallot@cirad.fr (A.F.); \\ jean-francois.le_coq@cirad.fr (J.-F.L.C.); eric.sabourin@cirad.fr (E.S.) \\ 2 Center for International Forestry Research, CIFOR, 12 Lima, Peru \\ 3 Center for Climate and Resilience Research (CR2), Department of Environmental Science and Resource \\ Management, University of Chile, 8820000 Santiago, Chile; paldunce@uchile.cl \\ 4 International Center for Tropical Agriculture (CIAT), 76520000 Cali, Colombia; j.tapasco@cgiar.org \\ 5 Center for Sustainable Development, University of Brasília, 70910-900 Brasilia, Brazil \\ * Correspondence: bruno.locatelli@cirad.fr; Tel.: +51-13-496-017
}

Received: 1 September 2017; Accepted: 2 October 2017; Published: 12 October 2017

\begin{abstract}
Research on climate change policies can contribute to policy development by building an understanding of the barriers faced in policy processes, and by providing knowledge needed throughout policy cycles. This paper explores the thematic coverage of research on climate change policies related to rural areas, rural development, and natural resource management in Latin America. A three-tier framework is proposed to analyse the selected literature. The results show that research studies have focussed on the mitigation of greenhouse gas emissions from forests, and adaptations to climate change in agriculture. There is little policy research on other vulnerable sectors (e.g., water and health) and emitting sectors (e.g., energy and industry) in the context of rural development. Our analysis highlights the various research gaps that deserve increased scientific attention, including: cross-sector approaches, multi-level governance, and the stages of policy adoption, implementation and evaluation. In addition, the selected literature has a limited contribution to theoretical discussions in policy sciences.
\end{abstract}

Keywords: policy research; adaptation; mitigation; natural resources; forest; agriculture

\section{Introduction}

Policies are essential for addressing the multiple challenges of climate change and supporting adaptation (reducing the vulnerability of people and ecosystems to climate change) or mitigation activities (reducing greenhouse gas accumulation in the atmosphere) [1]. Climate change links strongly with a number of other policy domains. As such, it can be mainstreamed in sectoral policies within the agriculture, forestry, rural development, nature protection, disaster risk management, energy, and finance sectors [2], as much as specific climate policies can be designed [3].

The formulation and implementation of effective policies for fighting climate change is limited by several types of barriers. These include uncertainties on climate impacts, and lack of awareness, or perhaps even political willingness $[4,5]$. Research on climate change policies can contribute to policy development in several ways, such as helping to build an understanding of the barriers faced in policy processes, providing knowledge, and raising awareness throughout policy cycles [6]. Policy development can be supported by both analytic descriptive and solution-oriented research that is built on multidisciplinary research and strong disciplinary knowledge [7].

Although most of the literature on climate change is written from a natural sciences perspective, climate change has recently seen an increase in attention in the social and political sciences [8]. 
Before 2010, only around 5\% of the scientific papers published on climate change were written from a social science perspective [9]. The number of studies on the social and policy dimensions of climate change has since increased [10], although not significantly. Further policy research could see important contributions to climate change policy development [11]. A bibliometric analysis of the literature on climate change policies showed a dominance of publications in journals with thematic and interdisciplinary orientations, as well as in journals focusing on economics, and a dominance of empirical case studies without theory development [12]. To complement this analysis of journals and disciplines, it would prove useful to explore the diversity of topics, issues, and approaches we see across climate change policy research.

This study focussed on Latin America, a diverse region with wide-ranging levels of greenhouse gas emissions and vulnerability to climate variations (see Supplementary Materials for the list of 19 countries included in the analysis from Central and South America and the Caribbean). Three of the selected countries are among the world's top 20 largest emitters of greenhouse gases, and six are among the top 20 largest emitters from land-use change and forestry [13]. Leadership on climate change issues has emerged among Latin American countries, with contrasting positions. For example, countries in the Bolivarian Alliance for the Peoples of our America (ALBA in Spanish) have denounced the injustice of climate change and called for developed countries to cut their emissions, whereas countries in the Association of Independent Latin American and Caribbean states (AILAC) have announced their willingness to pursue low-carbon development without waiting for all of the developed countries to engage in such efforts [14,15].

In this study, we analyse the thematic coverage of climate change policy analysis research, with a focus on policies related to rural areas, rural development, and natural resource management. We propose a framework for analysing research on climate change policies and apply it to selected publications on Latin America. We consider research on policies specifically designed to respond to climate change, as well other policies that can affect climate change mitigation, through their impacts on greenhouse gas emissions, and adaptation, through their impacts on the vulnerability of people and ecosystems to climate change.

\section{Materials and Methods}

\subsection{Analytical Framework}

A three-tier framework was developed to analyse the selected literature. The first level uses the typology of policy analysis developed by Gordon et al. [16], which distinguishes two different explicit purposes of policy analysis ('analysis of policy' and 'analysis for policy') and five related research activities (Figure 1 left). The 'analysis of policy' purpose refers to two types of research. The first focusses on policy content, and includes descriptive academic accounts of particular policies, with possibly historical or critical analysis of their content. The second looks at policy determination, and focusses on how policies are made and what inputs and transformational processes operate [16]. The 'analysis for policy' purpose includes research that is producing information or advice to policymakers. This research can provide data to feed into policy-making, or further explore causal relationships in the policy problem and suggest policy options. This purpose also includes policy advocacy research, which intends to influence the policy agenda towards an end valued by researchers. With a contribution to both purposes, policy monitoring and evaluation at the final stages of a policy process analyse how policies have performed, which can help policy revision or other policy development [17].

The second level of our framework relates to the stages of the policy cycle, a widely used representation of a policy process evolving through a sequence of discrete stages [18-20]. Five stages are often considered in a policy cycle: agenda setting (identification of a problem that deserves attention in the political agenda), policy formulation (dialogue between stakeholders and definition of goals and strategies, as well as an exploration and appraisal of options for addressing the problem), policy legitimation and adoption (decision on a course of action, mobilisation of political support, 
formal enactment), policy implementation (determination of roles and responsibilities of implementing agencies, allocation of resources), and evaluation (assessment of policy effectiveness in terms of problem-solving and unintended effects) $[19,20]$.

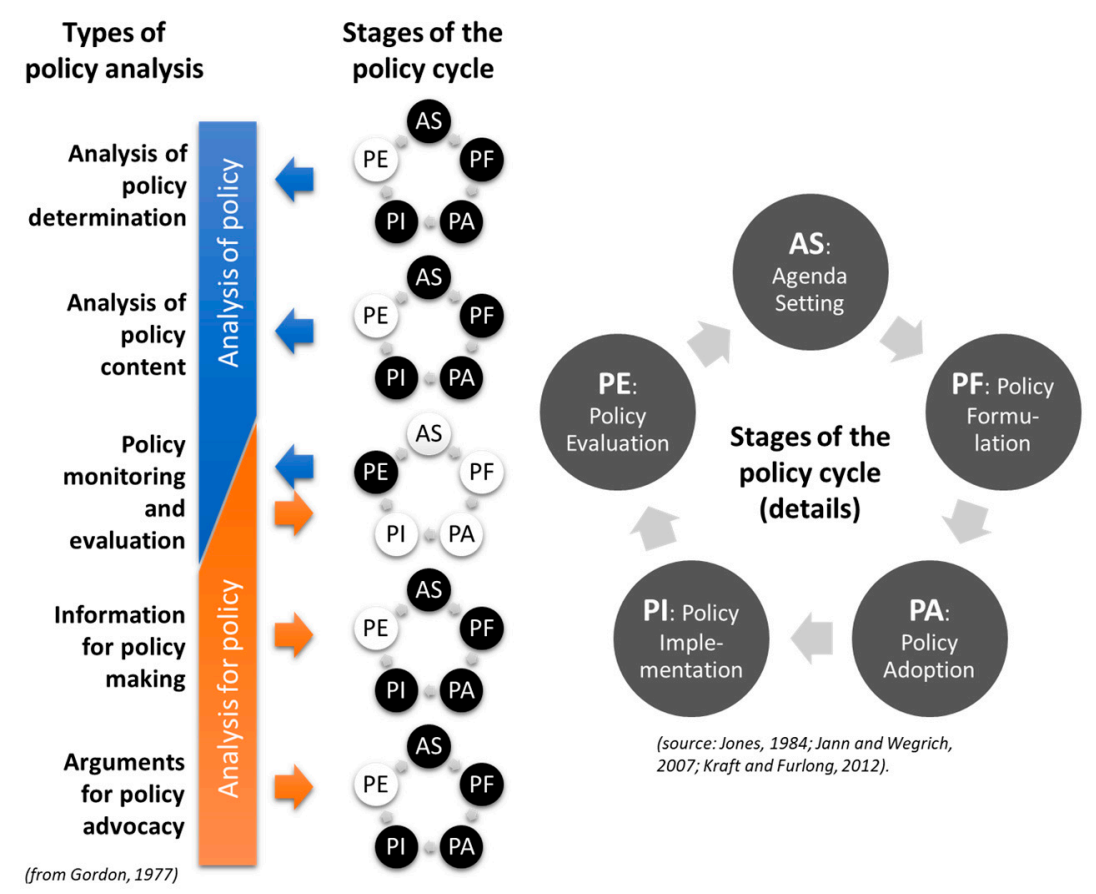

Figure 1. Framework for analysing research on climate change policies: types of policy analysis and stages of the policy cycle (the dark circles in the small policy cycle diagrams show the most likely stages addressed by a type of policy analysis).

The third level of our framework relates to policy research questions and approaches. After each document was classified according the first two levels of the analytical framework, research questions were identified, for example: questions on policy problems, policy content, roles, policy actors (e.g., their role, attitudes and behaviour, the position of interest groups), and policy consequences, among others. In addition, each document was classified according to sector (e.g., agriculture or forestry), relevant climate objectives (mitigation, adaptation including disaster risk reduction, or both), and theoretical references, particularly for explanatory analyses, which generally relied more on theoretical framework (e.g., the advocacy coalition framework or policy networks models) than descriptive analyses [21].

\subsection{Literature Search}

We used two complementary search procedures to identify research documents published since 2000 on climate change policy in relation to rural areas (including peer-reviewed articles, reports, briefs, and books produced by a diversity of writers from universities, think tanks, independent research institutions, and policy units of governments or international organisations). Firstly, we searched scientific journal papers in Web of Science (www.webofknowledge.com) and Scielo (www.scielo.org, a publication database focusing on Latin America) on 15 January 2016 with keywords related to climate change policies, rural development, rural environment (agriculture, forestry, land, ecosystem, or livelihoods), and Latin America (see Section 1 of the Supplementary Materials with details on the search). The query resulted in more than 200 records. Seven from Scielo and 42 from Web of Science were finally selected, after abstract examination. Secondly, we searched other documents, mainly reports and policy briefs, by browsing major websites related to climate change policies (see the list in Section 2 of the Supplementary Information) and querying Google and Google Scholar with similar 
keywords as the ones used in the first procedure. We found 92 additional documents, which led to an overall total of 141 documents (see the full list in Section 4 of the Supplementary Information).

Selected literature was analysed using the predefined framework. We built an Excel database with the following information for each document: policy research type, policy cycle stage, sector(s), climate objective(s), theoretical references, and one or multiple research question(s). We manually clustered papers with similar research questions within groups of documents of a given type of policy analysis at a given stage of the policy cycle.

Among the selected 54 journal articles and 87 other publications (mostly reports), most of the documents dealt with a single country (as was found to be the case in 86 of the documents selected, which collectively focused on 16 out of the 19 selected countries in Latin America). Other documents covered multiple countries in Central America (4), South America (8), or over the Latin American continent (43). Peru and Brazil were the most represented countries in the sample, with more than 10 publications specific to these countries (see Section 3 in the Supplementary Information). Most of the publications addressed one single climate change policy objective (41 publications on mitigation and 44 on adaptation) rather than both objectives (56 publications).

\section{Results}

The analysis of research questions in the selected papers led to a typology of 19 main issues related to climate change policies, covering five types of analysis (Figure 2). Seven of these issues dealt with the first stage of the policy cycle, agenda setting. Seven dealt with the phases of formulation, adoption, and implementation. The final three issues referred to the evaluation phase. There was a high number of documents focusing on situation analysis (as part of information for policy making, in the stage of agenda setting) and the integration of climate in policy content (as part of the analysis of policy content in the stages of formulation to implementation) (see issues $\mathrm{d} 1 \mathrm{and} \mathrm{b} 2$ in Figure 2).

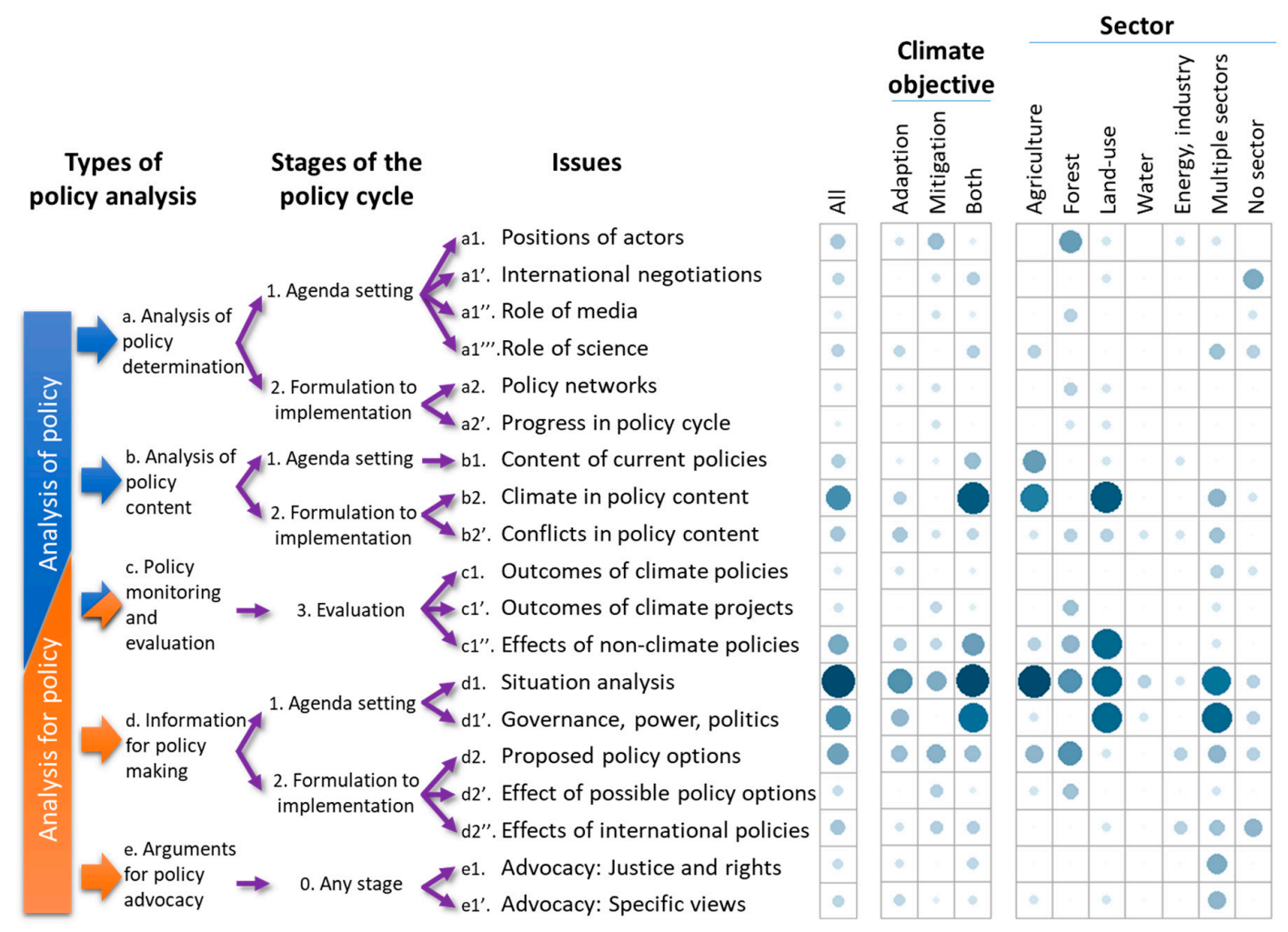

Figure 2. Major issues addressed by the selected documents according to policy analysis type and policy cycle stage. The three tables on the right show the frequency of issues associated with climate objectives and sectors in the selected documents (circle diameters are proportional to the number of documents). 
Many of the documents dealt with at least one of three associations of climate objectives and sectors (Figure 3): adaptation in agriculture, mitigation in forests, and both adaptation and mitigation in land-use in general. The focus on these three associations (which will be described in details in Section 3.2) was justified by the vulnerability of agriculture to climate variations, and the emissions caused by deforestation [22]. There was little to no research on other vulnerable sectors (e.g., water or health) or other emitting sectors (e.g., energy and industry) in the context of rural development.

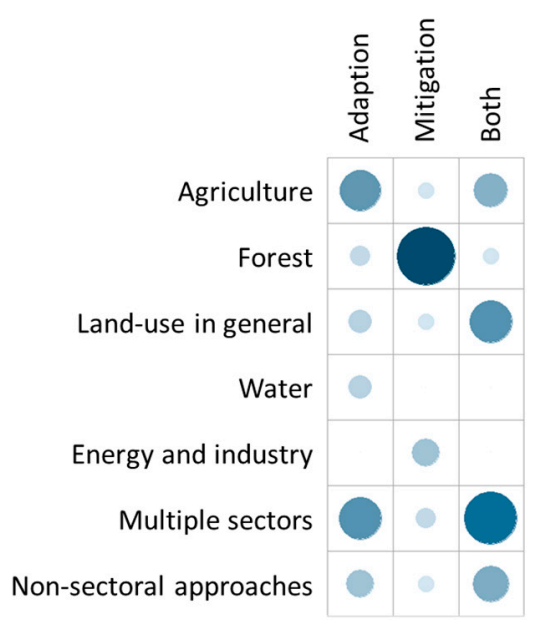

Figure 3. Frequency of associations of climate objectives and sectors in the selected documents (circle diameters are proportional to the number of documents).

\subsection{Main Issues and Questions by Type of Policy Analysis and Stage of the Policy Cycle}

\subsubsection{Analysis of Policy Determination}

Publications on policy determination mostly focussed on the stage of agenda setting (see issues a1 in Figure 2). Many of the papers identified the most relevant actors concerned by a climate-related issue, and their interests and positions towards a policy problem, for example the development of bio-fuels for climate change mitigation in Colombia [23]. Biases in agenda setting were sometimes highlighted, such as for example the bias of Latin-American adaptation agendas towards the technical aspects of adaptation, rather than its highly political aspects [24].

The positions of Latin American countries in international negotiations on climate change were analysed [25], which included the positions of specific countries [26], their positions on specific negotiation topics such as land use, land-use change, and forestry [27], or the role that Latin America could have in developing an international agreement on climate change [28].

The role of the media in agenda setting was a topic of research, such as, for example, how newspapers frame international negotiations on climate change in Argentina and Brazil [29]. The role of science was another topic, such as for example how and by whom scientific climate predictions were used for agenda setting [30]. On a related topic, one publication analysed how the discourses of climate sceptics influenced political discourses, and how better interdisciplinary work could improve the dissemination of science for policy development [31]. The science-policy gap on global environmental change was also analysed, as well the role of regional knowledge networks in bridging this gap [32].

Few policy determination analyses addressed policy cycle stages beyond agenda setting (i.e., formulation, adoption, or implementation). Some studies focused on how actors interacted through policy networks, such as for example how bridging organisations in governance networks can foster ecosystem-based adaptation in Costa Rica [33]. Progresses in climate policy cycles were also assessed, such as for example how the international context promoted the emergence of environmental policy instruments in Colombia [34]. Analyses also included the identification of driving forces and barriers to the development and implementation of climate policies in countries such as Costa Rica [35]. 


\subsubsection{Analysis of Policy Content}

The content of current policies and strategies was analysed with regard to their consideration of climate change issues, such as how adaptation was considered in the agriculture, forest, and water sectors in Chile, for example [36], or how the disaster risk management activities of the Inter-American Development Bank had considered climate change [37]. Many studies analysed policy content to understand how countries had progressed in integrating climate change issues [38], often with a multi-sector approach that included development, spatial planning, education, and energy policies in El Salvador [39].

The trade-offs or conflicts between climate and other policy domains were also topics of research, such as those between climate change policies and freshwater resources [40], or between biofuel low-carbon policies and health in Colombia [41]. Other trade-offs were related to how local communities and regional governments differed in their responses to climate change [42], or how adaptation projects and policies resulted in gender-differentiated effects [43].

\subsubsection{Policy Monitoring and Evaluation}

There were few publications assessing the outcomes of climate policies such as the National Action Plan for Climate Change in Chile [44], or climate projects such as carbon forestry projects [45]. The outcomes of disaster risk management policies have been studied to provide lessons for the current and future development of adaptation policies. These include analyses of governance capacities and best practices for the governance of disaster risk management [46], a better understanding of what determines the distribution of disaster risk reduction public spending in Peru [47], and an evaluation of the outcomes of institutional capacity building in health and disaster programmes [48].

\subsubsection{Information for Policy Making}

Situation analyses provided information that is potentially useful for agenda setting, such as descriptions of the climatic problem and its causes, the required policy transformations, or the context of these transformations. Several analyses simultaneously described problems of mitigation (emissions) and adaptation (vulnerability), as well as current policy and institutional context, such as one on rural development in Guatemala [49], as well as other major Latin American cities [50]. Some situation analyses emphasised knowledge gaps and existing research, such as one document from Uruguay [51], or described challenges related to analysing vulnerability and communicating results to adaptation policy makers in Central America [52]. Some situation analyses focussed on mitigating problems such as the drivers of national emissions in Mexico [53], whereas other analyses focussed on adaptation, impacts, and vulnerability [54,55].

Other situation analyses for agenda setting described governance challenges for addressing climate change in local development [56]. Challenges included the lack of capacity of current institutions to address climate change [57], and the constraints imposed by institutional and legal frameworks nationally [58] or regionally [59]. Other publications analysed the interactions between climate strategies and power or politics, such as how political affiliations affected the level of drought assistance in Brazil [60], for example, or how emergency situations reinforced the power of elites in Venezuela [61], and how political structures and power influenced adaptation decisions by smallholders [62].

Regarding the stage of policy formulation, policy options were proposed by many publications; these included options to reduce emissions in Peru [63] or stimulate the growth of biofuels in Central America [64]. Policy options also included alternatives to improve the legitimacy and effectiveness of climate policies and reduce conflicts [65]. Studies also dealt with the effects of possible policy options, such as how adaptation and mitigation policies can provide development co-benefits through health improvement, technological development, or ecosystem conservation [66].

In order to support policy formulation or adoption, several studies explored how countries or industries could be affected positively or negatively by international policies [67]. These included, 
how changes in the international climate policies and energy markets would affect national energy sectors [68], and whether possible mitigation policies and carbon tariffs in developed nations could affect carbon-intensive industries in Latin America [69]. Papers described opportunities for governments and the private sector to benefit from new funding opportunities for climate change action [70], including carbon markets [71,72] and adaptation funds [73,74]. A cross-level analysis dealt with how international policies are translated into policy agendas at local and territorial levels, and how global issues interact with regional development priorities [75].

\subsubsection{Arguments for Policy Advocacy}

The identification of advocacy documents was not straightforward, as the boundary between policy advocacy and information for policy-making was not always clear. Some publications advocated for a better consideration of justice and rights issues in climate agenda setting. This included, for example, the rights of indigenous communities [76], the need to focus on poor people [77], the integration of local and traditional knowledge in adaptation policies, and the respect of gender equity in climate policies [78]. A few publications advocated for specific climate policy approaches, such as: a stronger focus on adaptation than on mitigation due to social vulnerability in Latin America [79], a focus on ecosystem-based approaches to adaptation [80], or increased implications for local people in designing measures for small-scale production systems [81].

\subsection{Focus on Three Associations of Sectors and Climate Objectives}

\subsubsection{Policy Research Related to Forests and Mitigation}

Forests have been high on the international policy agenda for climate change mitigation since the UNFCCC (United Nations Framework Convention on Climate Change) was created in 1992 [82]. Several policy instruments have been created to incentivise mitigation action in the forest sectors of developing countries, such as the CDM (Clean Development Mechanism) and the REDD+ mechanism (Reducing Emissions from Deforestation and forest Degradation). These instruments have justified research on multiple issues at different stages of the policy cycle (Table 1).

Table 1. Diversity of issues related to forests and climate mitigation policies in the selected publications.

\begin{tabular}{|c|c|c|}
\hline Issues $^{1}$ & Example Questions & Example Reference \\
\hline Positions of actors (a1) & $\begin{array}{l}\text { How do national and subnational stakeholders relate REDD+ } \\
\text { to biodiversity conservation and other policy issues in Peru? }\end{array}$ & [83] \\
\hline Role of media (a1") & How is the REDD+ policy process represented in the media? & {$[84]$} \\
\hline Policy networks (a2) & $\begin{array}{l}\text { How are policy networks structured, and how do they } \\
\text { explain REDD+ constraints and opportunities in Brazil? }\end{array}$ & [85] \\
\hline Progress in policy cycle (a2') & $\begin{array}{l}\text { Are approaches to reduce deforestation (sustainable supply } \\
\text { chains, domestic policies and finance, REDD+) } \\
\text { being implemented? }\end{array}$ & [86] \\
\hline Conflicts in policy content (b2') & What are the legal rights on carbon in Chile? & [87] \\
\hline Outcomes of climate projects (c1') & What can be learned from successful carbon initiatives? & {$[88]$} \\
\hline Effects of non-climate policies (c1") & $\begin{array}{l}\text { How have agriculture incentives and infrastructure } \\
\text { development affected deforestation in the } \\
\text { Peruvian Amazon? }\end{array}$ & [89] \\
\hline Situation analysis $(\mathrm{d} 1)$ & What are the drivers of deforestation in Bolivia? & [90] \\
\hline Proposed policy options (d2) & $\begin{array}{l}\text { What are the solutions currently proposed to reduce } \\
\text { deforestation? }\end{array}$ & [91] \\
\hline Effects of possible policy options ( $\left.\mathrm{d} 2^{\prime}\right)$ & $\begin{array}{l}\text { How can carbon payments and income taxes affect } \\
\text { deforestation in a market equilibrium framework? }\end{array}$ & [92] \\
\hline
\end{tabular}

\footnotetext{
${ }^{1}$ Issue references in parenthesis refer to the codes used in Figure 2.
} 
Most of the research on the role of the media and policy networks in climate policy development in Latin America has been conducted on the case of REDD+, and analysed how REDD+ is represented in the media in Brazil [93] and Peru [84], how actors interacted in a national REDD+ network for exchanging information or collaborating in Peru [94], and how the structure of policy networks explained REDD+ constraints and opportunities in Brazil [85].

The formulation of REDD+ policies has allowed research to analyse progress along policy cycles and assess outcomes, at least through the lens of pilot projects. Brazil and Colombia are making progress on increasing food production while sparing forests and lowering carbon emissions through sustainable supply chains, domestic policies, domestic finance, and REDD+ [86]. The design, implementation, and outcomes of several REDD+ projects were assessed considering their policy framework in order to draw lessons for future REDD+ policy design [45]. Similarly, the analysis of the outcomes of carbon initiatives, such as Scolel Te in Mexico [88], provided recommendations to policy makers that considered future forest mitigation policies.

In order to inform REDD+ processes, research studies looked at how previous initiatives to reduce deforestation worked, or how deforestation has been affected by agricultural policies or road development in Peru $[89,95]$. Information for policy formulation also included analyses of the effects of possible policy options. Examples referred to how carbon payments could affect deforestation in Paraguay [92], how investments in reforestation and clean technology promotion in agriculture and forestry can reduce emissions in Brazil [96], and how carbon payments can make low-carbon crop-livestock systems attractive to farmers in Brazil [97].

\subsubsection{Policy Research Related to Agriculture and Adaptation}

Because of its vulnerability to climate variations, the agriculture sector is reportedly more concerned by adaptation than mitigation. The research reviewed on agriculture and adaptation policies covered several stages of the policy process (see Table 2). Central to this body of literature were vulnerability studies, which analysed how past climate variations have affected farmers in conjunction with other exposure, such as changes in policies or markets [98]. Part of the vulnerability analysis was the analysis of climatic impacts on agroecosystems and the exploration of farmer perceptions of climate change and its implications [99]. Analysing the vulnerability of farmers to multiple economic or climatic stressors could help policy makers understand what determines the adaptive capacity of farmers [100] so that policy options can be proposed in order to reduce the vulnerability of the agricultural sector [101].

Table 2. Diversity of issues related to agriculture and climate adaptation policies in the selected publications.

\begin{tabular}{|c|c|c|}
\hline Issues ${ }^{1}$ & Example Questions & Example Reference \\
\hline Role of science (a1"') & $\begin{array}{l}\text { How can crucial information from vulnerability analyses } \\
\text { be communicated to adaptation policy makers? }\end{array}$ & [52] \\
\hline Content of current policies (b1) & $\begin{array}{l}\text { What policy instruments exist to manage climate risks in } \\
\text { rural areas and agriculture? }\end{array}$ & [102] \\
\hline Conflicts in policy content (b2') & $\begin{array}{l}\text { How do local rural and farming communities differ from } \\
\text { regional governments in their responses to climate change? }\end{array}$ & {$[42]$} \\
\hline Effects of non-climate policies (c1") & $\begin{array}{l}\text { How do agricultural policies and programmes help } \\
\text { farmers adapt to droughts? }\end{array}$ & [103] \\
\hline Situation analysis (d1) & $\begin{array}{l}\text { What determines farmer adaptations to climatic and } \\
\text { non-climatic stressors? }\end{array}$ & [98] \\
\hline Governance, power, politics (d1') & $\begin{array}{l}\text { What are the institutional barriers to adaptation } \\
\text { in agriculture? }\end{array}$ & [99] \\
\hline Proposed policy options (d2) & $\begin{array}{l}\text { What are the options for reducing vulnerability in the } \\
\text { agricultural sector? How can policies support adaptation? }\end{array}$ & [101] \\
\hline
\end{tabular}

\footnotetext{
${ }^{1}$ Issue references in parentheses refer to the codes used in Figure 2.
} 


\subsubsection{Policy Research Related to Land-Use and Climate Change in General}

Agriculture, forest, and other land uses were often considered together in policy analysis, and with both climate objectives in perspective [22]. For example, many publications analysed the content of current agricultural and forest policies, in order to understand how they contributed to mitigation (by affecting greenhouse gas emissions) and adaptation (by influencing farmers' vulnerability) (Table 3). The analysis of policy content identified the extent to which climate change had been integrated into current agricultural and forest policies [104]. The publications reported lessons learned from current policy failures. Such lessons could have a positive impact on future climate policies, and the coordination of different land-related ministries acting on climate change policies. Another noteworthy point was that of the possible trade-offs between the objectives of reducing emissions and reducing ecological or social vulnerability [105]. This has seen adaptation policies affect mitigation or vice-versa; as such, concerns have been raised regarding inconsistencies in the integration of climate objectives in the land-use sectors [106].

Table 3. Diversity of issues related to agriculture and climate adaptation policies in the selected publications.

\begin{tabular}{lll}
\hline \multicolumn{1}{c}{ Issues $^{1}$} & \multicolumn{1}{c}{ Example Questions } & Example Reference \\
\hline Climate in policy content $(\mathrm{b} 2)$ & $\begin{array}{l}\text { How has climate change been integrated into current } \\
\text { agriculture and forest policies? }\end{array}$ & [107] \\
\hline Conflicts in policy content $\left(\mathrm{b} 2^{\prime}\right)$ & $\begin{array}{l}\text { Are adaptation and mitigation addressed jointly in } \\
\text { climate-related policy documents? How are trade-offs } \\
\text { between adaptation and mitigation considered? }\end{array}$ & $\begin{array}{l}\text { How do current agricultural and forest policies affect } \\
\text { mitigation (emissions) and adaptation (vulnerability)? }\end{array}$ \\
\hline Effects of non-climate policies (c1") & $\begin{array}{l}\text { How effective are current policies (for example, forest } \\
\text { conservation policies)? }\end{array}$ \\
\hline Situation analysis $(\mathrm{d} 1)$ & $\begin{array}{l}\text { What climate change issues are seen with land-use sectors } \\
\text { (emissions and vulnerability)? }\end{array}$ \\
\hline Governance, power, politics $\left(\mathrm{d} 1^{\prime}\right)$ & $\begin{array}{l}\text { How are the different ministries that are concerned with } \\
\text { climate change in rural areas coordinated? }\end{array}$ \\
\hline Proposed policy options $(\mathrm{d} 2)$ & $\begin{array}{l}\text { How can climate policies in agriculture and forestry be } \\
\text { improved to increase their legitimacy and effectiveness? }\end{array}$ \\
\hline
\end{tabular}

${ }^{1}$ Issue references in parentheses refer to the codes used in Figure 2.

\section{Discussion and Conclusions}

\subsection{Diversity of Issues Highlighted by Our Framework}

This paper has proposed a framework to classify research topics on climate change policies. The combination of two simple frameworks allowed the grouping of papers into broad issues in which specific research topics could be identified. However, the classification of policy analysis types was not always straightforward because of the blurred lines between advocacy and information for policy. In addition, many of the papers did not focus on a specific policy cycle stage, but rather described a policy landscape with multiple policy cycles at different stages.

This analysis is inevitably subject to some limitations. First, the dynamic nature and diversity of this research field calls for regular updates of the classification categories, in order to catch emerging issues. Second, because of the geographical restriction to Latin America, some important research issues may be missing because they are relevant only globally or in other parts of the world. Despite these limitations, this analysis has highlighted a diversity of issues and research topics related to climate change policies.

The selected documents addressed both climate objectives (adaptation and mitigation) and multiple sectors relevant to rural development (predominantly agriculture and forestry, with a few documents on water, energy and industry). They referred to multiple policy stages, but with many 
more publications available on the early stage of agenda setting. The selected documents were both analytic descriptive (mostly related to 'Analysis of Policy') and solution-oriented (mostly 'Analysis for Policy').

\subsection{Theories and Approaches in the Literature}

Many of the selected publications featured empirical and descriptive case studies that presented a policy context, identified key stakeholders, or analysed policy document contents, without theoretical reference to policy sciences or other disciplines. This gap might be explained by the publication selection process, which included reports and briefs from think tanks or policy units of governments or international organisations, and not only journal papers written by academic researchers.

Few publications referred to theoretical backgrounds. The policy theories or frameworks referenced by these publications included multiple streams [41], policy networks [85], and institutional analysis [112]. Some of the publications used economic approaches and models to analyse policies [92]. The lack of theoretical background might be explained by the interdisciplinary approach of most publications, but it also might be because traditional disciplines that focus on policy and politics may not have yet adopted climate change, a recent policy issue in most countries, as a research topic [12]. There may also be a disconnect between scholars contributing to theoretical and conceptual advancement and those working on empirical assessments of climate policy development [113]. In addition, solution-oriented analysts may prefer loose ties to theoretical backgrounds and academic schools of thoughts in order to broaden their readership and favour the involvement of policy actors in a learning process [114].

The focus of the documents analysed was on policies, rather than politics. Only a few publications dealt with the interactions between climate change policies and politics or power $[60,61]$, or contributed to political debates related to climate change. For example, only a few documents reflected on environmental citizenship [30] or neoliberalism [115], and thus were contributing to a broader discussion on the interactions between nature and society or the effect of economic liberalisation on climate change [12]. Other scholars have called researchers to engage more in the political processes that shape the development of climate policies and to propose more radical criticisms to the root causes of climate change and the assumptions of some climate policies, including liberalisation, privatisation, and marketisation [113].

\subsection{Research Gaps and Needs}

Our analysis highlights various research gaps that deserve increased scientific attention. Firstly, some countries were not addressed by any of the selected publications: Cuba, Honduras, and Nicaragua. Secondly, the study highlighted a need for more research on vulnerable sectors (e.g., water and health) and emitting sectors (e.g., energy and industry) besides agriculture and forests, which are largely represented in the literature on climate change policies in Latin America, because of their importance in national economies and in relation to climate change. Another reason for this focus on forests and agriculture is that climate change discussions have often reduced the climate change problem to an issue of natural resource management, rather than a broader societal problem [116].

Thirdly, there were relatively few studies that focussed on the interactions between economic sectors and between multiple levels of governance, such as between national and subnational levels, for example. The call for more research on cross-sector approaches and multi-level governance has been also made elsewhere [12]. A fourth gap noted was regarding the relatively few studies available on the stages of policy adoption, implementation, and evaluation, most likely because the climate policies are too recent. Future research efforts should focus on those policy process stages. Finally, it was noted that research on climate change policies in Latin America could contribute more to theoretical discussions in policy sciences through the production of more scholarly publications [117]. 


\subsection{Recommendations}

The two complementary types of research considered here, 'science for climate policies' and 'science of climate policies', should be strengthened in order to better support climate policy development in Latin America. As the authors of a large body of literature on solution-oriented research ('science for climate policies') cannot expect policy makers to read their publications, there is also a need to build or improve communication channels between science and policy in order to foster policy action on climate-related problems [118]. We also need more analyses of policy processes in order to understand why adequately communicated policy-relevant research results fail to influence policy development [119]. More fundamental inquiry can improve our understanding of climate policy processes through theory and concept development. The 'science of climate policies' needs to be strengthened by integrating recent disciplinary works from science domains other than climate change [7].

Supplementary Materials: One document is available online at www.mdpi.com/2071-1050/9/10/1831/s1 with the following information: (i) Keywords used in the search for journal papers; (ii) Selected websites for searching policy analysis documents; (iii) Sample description; and (iv) Full list of selected publications.

Acknowledgments: The funding partners that have supported this research include the International Climate Initiative (IKI) of the German Federal Ministry for the Environment, Nature Conservation, Building and Nuclear Safety (BMUB), the Norwegian Agency for Development Cooperation, and the CGIAR Research Program on Forests, Trees and Agroforestry (CRP-FTA) with financial support from the CGIAR Fund. The authors thank the "Public Policy and rural development in Latin America (PP-AL)" network (managed by Cirad), which organized a workshop in Brasilia in October 2015, where this study was initiated. They also thank Gilles Massardier for his advice on conceptual frameworks.

Author Contributions: All authors conceived and designed the study; B.L. performed the review and analysed the data; All authors wrote the paper.

Conflicts of Interest: The authors declare no conflict of interest.

\section{References}

1. Intergovernmental Panel on Climate Change (IPCC). Climate Change 2014: Synthesis Report; Contribution of Working Groups I, II and III to the Fifth Assessment Report of the IPCC; Intergovernmental Panel on Climate Change: Geneva, Switzerland, 2014; p. 151.

2. Kok, M.T.J.; de Coninck, H.C. Widening the scope of policies to address climate change: Directions for mainstreaming. Environ. Sci. Policy 2007, 10, 587-599. [CrossRef]

3. Di Gregorio, M.; Nurrochmat, D.R.; Paavola, J.; Sari, I.M.; Fatorelli, L.; Pramova, E.; Locatelli, B.; Brockhaus, M.; Kusumadewi, S.D. Climate policy integration in the land use sector: Mitigation, adaptation and sustainable development linkages. Environ. Sci. Policy 2017, 67, 35-43. [CrossRef]

4. Clar, C.; Prutsch, A.; Steurer, R. Barriers and guidelines for public policies on climate change adaptation: A missed opportunity of scientific knowledge-brokerage. Nat. Resour. Forum 2013, 37, 1-18. [CrossRef]

5. Aldunce, P.; Handmer, J.; Beilin, R.; Howden, M. Is climate change framed as 'business as usual' or as a challenging issue? The practitioners' dilemma. Environ. Plan. C Gov. Policy 2016, 34, 999-1019. [CrossRef]

6. Norse, D.; Tschirley, J.B. Links between science and policy making. Agric. Ecosyst. Environ. 2000, 82, 15-26. [CrossRef]

7. Swart, R.; Biesbroek, R.; Capela Lourenço, T. Science of adaptation to climate change and science for adaptation. Interdiscip. Clim. Stud. 2014, 2, 29. [CrossRef]

8. Haunschild, R.; Bornmann, L.; Marx, W. Climate Change Research in View of Bibliometrics. PLoS ONE 2016, 11, e0160393. [CrossRef] [PubMed]

9. Grieneisen, M.L.; Zhang, M. The current status of climate change research. Nat. Clim. Chang. 2011, 1, 72-73. [CrossRef]

10. Härtel, C.E.; Pearman, G.I. Understanding and responding to the climate change issue: Towards a whole-of-science research agenda. J. Manag. Organ. 2010, 16, 16-47. [CrossRef]

11. Javeline, D. The Most Important Topic Political Scientists Are Not Studying: Adapting to Climate Change. Perspect. Politics 2014, 12, 420-434. [CrossRef] 
12. Rykkja, L.H.; Neby, S.; Hope, K.L. Implementation and governance: Current and future research on climate change policies. Public Policy Adm. 2014, 29, 106-130. [CrossRef]

13. World Resources Institute (WRI). CAIT Climate Data Explorer; World Resources Institute: Washington, DC, USA, 2017.

14. Edwards, G.; Roberts, J.T. A Fragmented Continent: Latin America and the Global Politics of Climate Change; MIT Press: Cambridge, MA, USA, 2015.

15. De la Torre, A.; Fajnzylber, P.; Nash, J. Low Carbon, High Growth: Latin American Responses to Climate Change: An Overview; World Bank Publications: Washington, DC, USA, 2009.

16. Gordon, I.; Lewis, J.; Young, K. Perspectives on policy analysis. Public Adm. Bull. 1977, 25, 26-30.

17. Parsons, W. Public Policy: An Introduction to the Theory and Practice of Policy Analysis; Edward Elgar Publishing: Cheltenham Glos, UK, 1997.

18. Jones, C.O. An Introduction to the Study of Public Policy, 3rd ed.; Brooks/Cole Pub. Co.: Pacific Grove, CA, USA, 1984.

19. Kraft, M.E.; Furlong, S.R. Public Policy: Politics, Analysis, and Alternatives; Sage: New York, NY, USA, 2012.

20. Jann, W.; Wegrich, K. Theories of the policy cycle. In Handbook of Public Policy Analysis: Theory, Politics and Methods; Fischer, F., Miller, G.J., Sidney, M.S., Eds.; CRC Press: Boca Raton, FL, USA, 2007; pp. 43-62.

21. Araral, E.; Fritzen, S.; Howlett, M.; Ramesh, M.; Wu, X. Routledge Handbook of Public Policy; Routledge: Abingdon-on-Thames, UK, 2012.

22. Di Gregorio, M.; Fatorelli, L.; Pramova, E.; May, P.; Locatelli, B.; Brockhaus, M. Integrating Mitigation and Adaptation in Climate and Land Use Policies in Brazil: A Policy Document Analysis; University of Leeds: Leeds, UK, 2016.

23. Mejía, A.S.L. Agrofuels policy in Colombia: Expectations and rural development. Agron. Colomb. 2011, 29, 133-140.

24. Lampis, A. La adaptación al cambio climático: El reto de las dobles agendas. In Cambio Climático, Movimientos Sociales y Políticas Públicas: Una Vinculación Necesaria; Postigo, J.C., Ed.; Consejo Latinoamericano de Ciencias Sociales, Instituto de Ciencias Alejandro Lipschutz (ICAL, Chile): Santiago, Chile, 2013.

25. Maurtua Konstantinidis, E. La Plataforma de Durban: Implicancias y Escenarios para Latinoamérica; Climate Action Network Latin America, Fundación Biosfera (Argentina): Buenos Aires, Argentina, 2012.

26. Villegas, E.; Sabogal Mogollón, J.; Camacho, A. Foro Nacional Sobre Cambio Climático: Después de Cancún y Hacia Durban, Estado de la Negociación y la Participación de Colombia; AVINA, WWF: Gland, Switzerland, 2011.

27. Estrada Porrua, M.; Garcia-Guerrero, A. A Latin American Perspective on Land Use, Land-Use Change, and Forestry Negotiations under the United Nations Framework Convention on Climate Change. In Climate Change and Forests: Emerging Policy and Market Opportunities; Streck, C., Osullivan, R., JansonSmith, T., Tarasofsky, R., Eds.; Chatham House: London, UK, 2008; pp. 209-222.

28. Garibaldi, J.A.; Araya, M.; Edwards, G. La Plataforma de Durban: El rol de América Latina y el Caribe en Forjar un Acuerdo Climático Ambicioso; Climate \& Development Knowledge Network, Fundación Futuro Latinoamericano, Energeia: London, UK, 2012.

29. Alcaraz, L.G. El framing como legitimación de la política climática: Encuadres del cambio climático en la prensa argentina y brasileña durante las conferencias de Doha y Varsovia. Anu. Electron. Estud. Comun. Soc. Disert. 2014, 7. [CrossRef]

30. Orlove, B.; Taddei, R.; Podesta, G.; Broad, K. Environmental citizenship in Latin America: Climate, Intermediate Organizations, and Political Subjects. Lat. Am. Res. Rev. 2011, 46, 115-140. [CrossRef]

31. Palacio, G. Cambio climático, retórica política y crisis ambiental: Una nueva interfase entre ciencias naturales y ciencias sociales. In Cambio Climático, Movimientos Sociales y Politicas Públicas: Una Vinculación Necesaria; Postigo, J.C., Ed.; Consejo Latinoamericano de Ciencias Sociales, Instituto de Ciencias Alejandro Lipschutz (ICAL, Chile): Santiago, Chile, 2013.

32. Lahsen, M.; Bustamante, M.M.C.; Swap, R.; McNie, E.; Ometto, J.P.H.B.; Schor, T.; Tiessen, H.; Andelman, S.; Annegarn, H. The Contributions of Regional Knowledge Networks Researching Environmental Changes in Latin America and Africa: A Synthesis of what they can do and why they can be policy relevant. Ecol. Soc. 2013, 18. [CrossRef]

33. Vignola, R.; McDaniels, T.L.; Scholz, R.W. Governance structures for ecosystem-based adaptation: Using policy-network analysis to identify key organizations for bridging information across scales and policy areas. Environ. Sci. Policy 2013, 31, 71-84. [CrossRef] 
34. Rodriguez R, K.J.; Avila Foucat, V.S. Instrumentos de política pública para la conservación: Su nacimiento y evolución en Colombia. Perf. Latinoam. 2014, 22, 127-158. [CrossRef]

35. Jiménez Gómez, R.; Amit, R.; Vindas, R. Politicas de Cambio Climático en Costa Rica, Integrando Esfuerzos Para Asumir Los Retos; Universidad Estatal a Distancia, Vicerrectoría de Investigación, Centro de Investigación en Cultura y Desarrollo: San José, Costa Rica, 2011.

36. Aldunce, P.; León, A.; Carvajal, Y.; Neri, C.; Quinteros, M.; Soza, S. Sistematización de las Políticas y Estrategias de Adaptación Nacional e Internacional al Cambio Climático del Sector Silvoagropecuario y de los Recursos Hídricos y Edáficos; Departamento de Ciencias Ambientales y Recursos Naturales Renovables, Universidad de Chile: Santiago, Chile, 2008.

37. Ashwill, M.; Alvarez, L. Climate Change and IDB: Building Resilience and Reducing Emissions, Sector Study: Disaster Risk Reduction; Inter-American Development Bank: Washington, DC, USA, 2014.

38. Begenisic, F.; Gracia, A.; Pascale, C.; Guarás, D.; Tognon, M.; Almada, M.; Maceira, J.; Dehyeralde, A.; Valli, S.; Occhiuzzi, S.; et al. Principales Políticas Sobre Cambio Climático en los Países del Consejo Agropecuario del Sur (CAS); Grupo ad hoc Agricultura, Variabilidad y Cambio Climático; Red de Coordinación de Políticas Agropecuarias (REDPA), IICA (Instituto Interamericano de Cooperación para la Agricultura): Santiago, Chile, 2010.

39. Cuéllar, N.; Luna, F.; Díaz, O.; Kandel, S. Cambio Climático y Desarrollo en El Salvador: Respuestas de Política y Desafios Para la Gestión Territorial; Fundación PRISMA: San Salvador, Salvador, 2013.

40. Pittock, J. National Climate Change Policies and Sustainable Water Management: Conflicts and Synergies. Ecol. Soc. 2011, 16, 25. [CrossRef]

41. García-Lozada, H. La dimensión salud: ¿Ignorada en la Política de Alcohol Carburante (PAC) en Colombia? Univ. Humaníst. 2009, 68, 269-286.

42. Postigo, J.C. Desencuentros y (potenciales) sinergias entre las respuestas de campesinos y autoridades regionales frente al cambio climático en el sur andino peruano. In Cambio Climático, Movimientos Sociales y Políticas Públicas: Una Vinculación Necesaria; Postigo, J.C., Ed.; Consejo Latinoamericano de Ciencias Sociales, Instituto de Ciencias Alejandro Lipschutz (ICAL, Chile): Santiago, Chile, 2013.

43. Píriz, C. Inclusión de la Dimensión de Género en las Políticas Territoriales Costeras y de Adaptación al Cambio Climático; Tercer Semana de Reflexión Sobre Cambio y Variabilidad Climática, Universidad de la República, Uruguay: Montevideo, Uruguay, 2011.

44. Aldunce, P.; Lillo, G.; Indvik, K.; Bórquez, R.; Paneque, M.; Montenegro, N.; Román-Figueroa, C.; Echeverría, I.; Rebolledo, I.; Farah, M.L.; et al. Evaluación Final del Plan Nacional de Acción de Cambio Climático 2008-2012; Ministerio del Medio Ambiente del Gobierno de Chile: Santiago, Chile, 2015.

45. Dulal, H.B.; Shah, K.U.; Sapkota, C. Reducing emissions from deforestation and forest degradation (REDD) projects: Lessons for future policy design and implementation. Int. J. Sustain. Dev. World Ecol. 2012, 19, 116-129. [CrossRef]

46. Lacambra, S.; Suárez, G.; Hori, T.; Rogers, C.; Salazar, L.P.; Corderi, D.; Esquivel, M. Índice de Gobernabilidad y de Politicas Públicas en Gestión del Riesgo de Desastres; Banco Interamericano de Desarrollo: Washington, DC, USA, 2014.

47. Miller, S.J.; Vela, M.A. Is Disaster Risk Reduction Spending Driven by the Occurrence of Natural Disasters? Evidence from Peru; Inter-American Development Bank: Washington, DC, USA, 2014.

48. Spiegel, J.M.; Breilh, J.; Beltran, E.; Parra, J.; Solis, F.; Yassi, A.; Rojas, A.; Orrego, E.; Henry, B.; Bowie, W.R.; et al. Establishing a community of practice of researchers, practitioners, policy-makers and communities to sustainably manage environmental health risks in Ecuador. BMC Int. Health Hum. Rights 2011, 11. [CrossRef] [PubMed]

49. Castellanos, E.J.; Guerra, A. Cambio Climático y desarrollo humano en Guatemala. Diálogo Político 2009, 26, 51-68.

50. Ryan, D.; Glover, S.; Cimolai, C. Desafíos Políticos e Institucionales de las Políticas Locales Sobre Cambio Climático: Las Experiencias de Buenos Aires, México D.F. y San Pablo; Fundación Ambiente y Recursos Naturales (FARN), Argentina: Buenos Aires, Argentina, 2012.

51. García Cartagena, M.; Toranza, C.; de Torres Álvarez, M.F. Proyectos, personas y publicaciones sobre cambio y variabilidad climática en Uruguay. In Cambio y Variabilidad Climática: Respuestas Interdisciplinarias; Picasso, V., Cruz, G., Astigarraga, L., Terra, R., Eds.; Espacio Interdisciplinario, Universidad de la República: Montevideo, Uruguay, 2012. 
52. Castellanos, E.J.; Tucker, C.; Eakin, H.; Morales, H.; Barrera, J.F.; Díaz, R. Assessing the adaptation strategies of farmers facing multiple stressors: Lessons from the Coffee and Global Changes project in Mesoamerica. Environ. Sci. Policy 2013, 26, 19-28. [CrossRef]

53. Cruz, G.; Terra, R.; Picasso, V.; Astigarraga, L.; Achkar, M.; Becoña, G.; Caorsi, L.; Gazzano, I.; Ceroni, M.; Torres, M.F.D.; et al. Cambio y Variabilidad Climática: Respuestas Interdisciplinarias; Espacio Interdisciplinario, Universidad de la República: Montevideo, Uruguay, 2012.

54. Cárdenas, M.; Rodríguez Becerra, M.; Ardila, G.; Andrade, G.I.; Benavides, J.; Carrizosa Umaña, J.; García Portilla, J.; Rudas Lleras, G.; Ruiz Soto, J.P. Desarrollo Económico y Adaptación al Cambio Climático; Friedrich Ebert Stiftung en Colombia (Fescol): Bogotá, Colombia, 2013.

55. Samaniego, J.; Galindo, L.M.; Alatorre, J.E.; Ferrer, J.; Gómez, J.J.; Lennox, J.; Reyes, O.; Sánchez, L. La Economía del Cambio Climático en América Latina y el Caribe: Paradojas y Desafíos del Desarrollo Sostenible; CEPAL: Santiago, Chile, 2014.

56. Cuéllar, N.; Luna, F.; Díaz, O.; Kandel, S. Gobernanza Ambiental-Territorial y Desarrollo en El Salvador: El Caso del Bajo Lempa. Available online: http:/ / biblioteca.clacso.edu.ar/clacso/engov/20131210114244/ WorkingPaperENGOV6_Cuellar_etal.pdf (accessed on 12 October 2017).

57. Fernández Bremauntz, A. Capacidades Institucionales para la Gestión del Cambio Climático: La Experiencia de México; Banco Interamericano de Desarrollo: Washington, DC, USA, 2012.

58. Ludeña, C.; Wilk, D. Ecuador: Mitigación y Adaptación al Cambio Climático, Marco de la Preparación de la Estrategia 2012-2017 del BID en Ecuador; Banco Interamericano de Desarrollo: Washington, DC, USA, 2013.

59. Rodríguez, A.; Saucedo, A.; Sotomayor, O.; van Wambeke, J.; Meza, L. Agricultura y Cambio Climático: Instituciones, Políticas e Innovación [Memoria del Seminario Internacional]; CEPAL, FAO: Santiago, Chile, 2011.

60. Bastos, P.; Miller, S. Politics under the Weather: Droughts, Parties and Electoral Outcomes; Inter-American Development Bank: Washington, DC, USA, 2013.

61. Fassin, D.; Vasquez, P. Humanitarian exception as the rule: The political theology of the 1999 Tragedia in Venezuela. Am. Ethnol. 2005, 32, 389-405. [CrossRef]

62. Wrathall, D.J.; Bury, J.; Carey, M.; Mark, B.; McKenzie, J.; Young, K.; Baraer, M.; French, A.; Rampini, C. Migration Amidst Climate Rigidity Traps: Resource Politics and Social-Ecological Possibilism in Honduras and Peru. Ann. Assoc. Am. Geogr. 2014, 104, 292-304. [CrossRef]

63. Gutiérrez, M.E.; García, D.; Morales, D.; Rueda, C.; Piscoya, M.; Guinand, L.E.; Bazán, M.; Echevarría, A.; Limachi, L.; Paredes, C. Mitigation Scenarios in Peru 2050: Towards a Low Emission Development; PlanCC: Lima, Peru, 2014.

64. Shah, K.U.; Philippidis, G.; Dulal, H.B.; Brodnig, G. Developing biofuels industry in small economies: Policy experiences and lessons from the caribbean basin initiative. Mitig. Adapt. Strateg. Glob. Chang. 2014, 19, 229-253. [CrossRef]

65. Lumerman, P.; Psathakis, J.; Ortiz, M.d.l.Á.; Asis, I. Desafíos Para un Desarrollo Compatible Con el Clima: Cómo Fortalecer las Políticas Públicas del Sector Agropecuario y Forestal; Plataforma Climática Latinoamericana, Fundación Cambio Democrático: Quito, Ecuador, 2012.

66. Vergara, W.; Rios, A.R.; Galindo, L.M.; Pablo, Gutman; Isbell, P.; Suding, P.H.; Samaniego, J. The Climate and Development Challenge for Latin America and the Caribbean: Options for Climate-Resilient, Low-Carbon Development; IDB Inter-American Development Bank, ECLAC Economic Commission for Latin America and the Caribbean: Washington, DC, USA, 2013.

67. Honty, G. Cambio Climático: Negociaciones y Consecuencias Para América Latina; CLAES-Centro Latino Americano de Ecología Social: Montevideo, Uruguay, 2011.

68. Acquatella, J. Energía y Cambio Climático: Oportunidades Para una Política Energética Integrada en América Latina y el Caribe; Comisión Económica para América Latina y el Caribe (CEPAL): Santiago, Chile, 2008.

69. Zotz, A.-K. Impact of Climate Change Mitigation Policies in OECD Countries on Carbon Emissions Intensive Export Industries in Latin America; Inter-American Development Bank: Washington, DC, USA, 2012.

70. Fankhauser, S.; Ward, J. Implicaciones Regionales de las Recomendaciones del Grupo Asesor Sobre Financiación del Clima (AGF): América Latina y el Caribe; Climate and Development Knowledge Network, Vivid Economics: London, UK, 2010.

71. Martino, D.L. El Mercado del Servicio de Mitigación del Cambio Climático: Oportunidades para Uruguay; Programa Apoyo a los Procesos de Apertura e Integración al Comercio Internacional (ICI) ATN/ME-9566-RG, Carbosur: Montevideo, Uruguay, 2008. 
72. Meirovich, H.; Peters, S.; Rios, A.R. Financial Instruments and Mechanisms for Climate Change Programs in Latin America and the Caribbean; Inter-American Development Bank, Climate Change and Sustainability Division: Washington, DC, USA, 2013.

73. Reyes, V.; Sánchez, R.; Mora, R.; Castro, R.; Madrigal, P.; Ovares, C.; Cascante, S. Mecanismos Financieros para la Adaptación al Cambio Climático del Parque Nacional Marino las Baulas y el Posible Corredor Entre Este Parque y el Parque Nacional Santa Rosa; BIOMARCC-SINAC-GIZ, Centro de Derecho Ambiental y de los Recursos Naturales (CEDARENA): San José, Costa Rica, 2013.

74. Ullrich, S. Mecanismos Financieros Para la Adaptación de las Áreas Marino-Costeras Protegidas; BIOMARCC-SINAC-GIZ: San José, Costa Rica, 2013.

75. Blanco Wells, G.; Fuenzalida, M.I. La construcción de agendas científicas sobre cambio climático y su influencia en la territorialización de políticas públicas: Reflexiones a partir del caso chileno. In Cambio Climático, Movimientos Sociales y Políticas Públicas: Una Vinculación Necesaria; Postigo, J.C., Ed.; Consejo Latinoamericano de Ciencias Sociales, Instituto de Ciencias Alejandro Lipschutz (ICAL, Chile): Santiago, Chile, 2013.

76. de la Cuadra, F. Cambio climático y conflicto socioambiental Apuntes sobre el antagonismo entre el pueblo mapuche, el Estado chileno y las empresas. In Cambio Climático, Movimientos Sociales y Políticas Públicas: Una Vinculación Necesaria; Postigo, J.C., Ed.; Consejo Latinoamericano de Ciencias Sociales, Instituto de Ciencias Alejandro Lipschutz (ICAL, Chile): Santiago, Chile, 2013.

77. Delgado, G.C.; Espina, M.; Sejenovich, H.; Guevara, C.A.E.; Zandvliet, H.; Martínez, J.L.; Panario, D.; Gutiérrez, O.; Carman, M.; Jiménez, E.; et al. Crisis Socioambiental y Cambio Climático; Consejo Latinoamericano de Ciencias Sociales-Conselho Latino-americano de Ciências Sociais: Buenos Aires, Argentina, 2013.

78. Melo Cevallos, M.; Rodríguez, A.S.; Laborde, R.E.; Narváez, R.; Latorre, L.; Pérez Castellón, A. Documento Descriptivo, Analítico y Comparativo de las Políticas Públicas Sobre Cambio Climático en Colombia, Ecuador, Perú y Bolivia y su Relación Con el Conocimiento Tradicional; UICN: Quito, Ecuador, 2014; p. 37.

79. Honty, G. América Latina ante el cambio climático. Observatorio de la Globalización, CLAES, Marzo [Disponible en www. energiasur. org]; CLAES: Montevideo, Uruguay, 2007.

80. Andrade, A.; Vides, R. Enfoque Ecosistémico y Políticas Públicas: Aportes Para la Conservación de la Biodiversidad y la Adaptación al Cambio Climático en Latinoamérica; Inter-American Institute for Global Change Research (IAI), CIIFEN, MacArthur Foundation: São José dos Campos, Brasil, 2010.

81. Pokorny, B.; de Jong, W.; Godar, J.; Pacheco, P.; Johnson, J. From large to small: Reorienting rural development policies in response to climate change, food security and poverty. For. Policy Econ. 2013, 36, 52-59. [CrossRef]

82. Angelsen, A.; Brockhaus, M.; Sunderlin, W.; Verchot, L. Analysing REDD+: Challenges and Choices; CIFOR, Center for International Forestry Research: Bogor, Indonesia, 2012.

83. Entenmann, S.K.; Schmitt, C.B. Actors' perceptions of forest biodiversity values and policy issues related to REDD plus implementation in Peru. Biodivers. Conserv. 2013, 22, 1229-1254. [CrossRef]

84. Perla Alvarez, J.; Freundt Montero, D.; Burga Barrantes, E.; Postigo Takahashi, T.; Menton, M. Políticas REDD+ y los Medios de Comunicación: Caso de Estudio en el Perú; Center for International Forestry Research (CIFOR): Bogor, Indonesia, 2012.

85. Gebara, M.F.; Fatorelli, L.; May, P.; Zhang, S. REDD+ policy networks in Brazil: Constraints and opportunities for successful policy making. Ecol. Soc. 2014, 19. [CrossRef]

86. Nepstad, D.; Irawan, S.; Bezerra, T.; Boyd, W.; Stickler, C.; Shimada, J.; Carvalho, O., Jr.; MacIntyre, K.; Dohong, A.; Alencar, A.; et al. More food, more forests, fewer emissions, better livelihoods: linking REDD plus, sustainable supply chains and domestic policy in Brazil, Indonesia and Colombia. Carbon Manag. 2013, 4, 639-658. [CrossRef]

87. Herve, D.; Claro, E. Characterizing Sequestration Rights Legally in Chile. In Climate Change and Forests: Emerging Policy and Market Opportunities; Streck, C., Osullivan, R., JansonSmith, T., Tarasofsky, R., Eds.; Chatham House: London, UK, 2008; pp. 148-162.

88. Ruiz-De-Ona-Plaza, C.; Soto-Pinto, L.; Paladino, S.; Morales, F.; Esquivel, E. Constructing Public Policy in a Participatory Manner: From Local Carbon Sequestration Projects to Network Governance in Chiapas, Mexico. In Carbon Sequestration Potential of Agroforestry Systems: Oppoortunities and Challenges; Kumar, B.M., Nair, P.K.R., Eds.; Springer International Publishing AG: Basel, Switzerland, 2011; Volume 8, pp. 247-262.

89. Chavez, A.B.; Broadbent, E.N.; Zambrano, A.M.A. Smallholder policy adoption and land cover change in the southeastern Peruvian Amazon: A twenty-year perspective. Appl. Geogr. 2014, 53, 223-233. [CrossRef] 
90. Mueller, R.; Pacheco, P.; Montero, J.C. El Contexto de la Deforestación y Degradación de los Bosques en Bolivia: Causas, Actores e Instituciones; Center for International Forestry Research (CIFOR): Bogor, Indonesia, 2014.

91. Galiani, S.; Puente, M.; Weinschelbaum, F. How Can Latin America Help the World to Cope with Climate Change? The Issue of Deforestation; Inter-American Development Bank, Department of Research and Chief Economist: Washington, DC, USA, 2013.

92. Barua, S.K.; Uusivuori, J.; Kuuluvainen, J. Impacts of carbon-based policy instruments and taxes on tropical deforestation. Ecol. Econ. 2012, 73, 211-219. [CrossRef]

93. May, P.H.; Calixto, B.; Gebara, M.F. A Política de REDD+ na Mídia: Um Estudo de Caso do Brasil; Center for International Forestry Research (CIFOR): Bogor, Indonesia, 2011.

94. Menton, M.; Perla, J.; Sotes, J.; Fatorelli, L. Análisis de las Redes Políticas de REDD+ en Perú; CIFOR: Bogor, Indonesia, 2014.

95. Chavez, A.B.; Perz, S.G. Adoption of Policy Incentives and Land Use: Lessons From Frontier Agriculture in Southeastern Peru. Hum. Ecol. 2012, 40, 525-539. [CrossRef]

96. Caetano, M.A.L.; Marcolino Gherardi, D.F.; Yoneyama, T. An optimized policy for the reduction of $\mathrm{CO}_{2}$ emission in the Brazilian Legal Amazon. Ecol. Model. 2011, 222, 2835-2840. [CrossRef]

97. Fernandes, M.d.S.; Alves Finco, M.V. Integrated crop-livestock systems and climate change policies. Pesqui. Agropecu. Trop. 2014, 44, 182-190. [CrossRef]

98. Tucker, C.M.; Eakin, H.; Castellanos, E.J. Perceptions of risk and adaptation: coffee producers, market shocks, and extreme weather in Central America and Mexico. Glob. Environ. Chang. 2010, 20, 23-32. [CrossRef]

99. Oyhantcabal, W.; Sancho, D.; Galván, M. Clima de Cambios: Nuevos Desafíos de Adaptación en Uruguay; Ministerio de Ganaderia, Agricultura y Pesca; FAO; Proyecto TCP/URU/3302 Nuevas Políticas para la Adaptación de la Agricultura al Cambio Climático: Montevideo, Uruguay, 2013.

100. Groenewald, S.F.; Van den Berg, M.M. Smallholder Livelihood Adaptation in the Context of Neoliberal Policy Reforms: A Case of Maize Farmers in Southern Veracruz, Mexico. J. Dev. Stud. 2012, 48, 429-444. [CrossRef]

101. Rosas, J.F.; Arboleya, I.; Carriquiry, M.A.; Licandro, H.; Millán, J.; Picasso, V. Estudio Sobre Políticas Públicas y Medidas de Adaptación del Sector Agropecuario al Cambio Climático (Volumen 7, Clima de Cambios); Ministerio de Ganaderia, Agricultura y Pesca/FAO/Proyecto TCP/URU/3302 Nuevas Políticas para la Adaptación de la Agricultura al Cambio Climático: Montevideo, Uruguay, 2013.

102. Soulé, A.Y.; Nilo, L.V.; Maturana, B.O.; Pensa, G.A.; Alfaro, M.P.; Cárdenas, G.R.; Donoso, I.S.; Rodríguez, M.; Catalán, W.A. Instrumentos de Fomento y Apoyo a la Gestión del Riesgo Agroclimático; Unidad Nacional de Emergencias Agrícolas y Gestión del Riesgo Agroclimático (UNEA), Ministerio de Agricultura: Santiago, Chile, 2014.

103. Bravo Peña, L.C.; Castellanos Villegas, A.E.; Doode Matsumoto, O.S. Sequía agropecuaria y vulnerabilidad en el centro oriente de Sonora: Un caso de estudio enfocado a la actividad ganadera de producción y exportación de becerros. Estud. Soc. 2010, 18, 209-241.

104. Ryan, D. Informe Sobre el Estado y Calidad de las Politicas Públicas Sobre Cambio Climático y Desarrollo en América Latina: Sector Agropecuario y Forestal; Plataforma Climática Latinoamericana: Quito, Ecuador, 2012.

105. Chazarin, F.; Locatelli, B.; Garay-Rodríguez, M. Mitigación en la selva, adaptación en la sierra y la costa: $i$ Oportunidades perdidas de sinergias frente al cambio climático en Perú. Ambient. Desarro. 2014, 18, 95-107. [CrossRef]

106. Locatelli, B.; Evans, V.; Wardell, A.; Andrade, A.; Vignola, R. Forests and Climate Change in Latin America: Linking Adaptation and Mitigation. Forests 2011, 2, 431-450. [CrossRef]

107. Albán, M.A.; Prócel, A. Informe Sobre el Estado Y Calidad de las Políticas Públicas Sobre Cambio Climático y Desarrollo en Ecuador: Sector Agropecuario y Forestal; Plataforma Climática Latinoamericana: Quito, Ecuador, 2012.

108. Pramova, E.; Di Gregorio, M.; Locatelli, B. Integrating Adaptation and Mitigation in Climate Change and Land-Use Policies in Peru; CIFOR: Bogor, Indonesia, 2015.

109. Cardoso, D.; Bidermann, R.; Betiol, L.; Valente, L. Informe Sobre o Estado e Qualidade das Políticas Públicas sobre Mudanças Climáticas e Desenvolvimento no Brasil. Um Panorama Geral, com Destaque ao Setor de Agricultura, Florestas e Outros Usos Do Solo; Plataforma Climática Latinoamericana: Quito, Ecuador, 2012.

110. Cuéllar, N.; Luna, F.; Díaz, O.; Kandel, S. Informe Sobre el Estado y Calidad de las Políticas Públicas Sobre Cambio Climático y Desarrollo en El Salvador; Plataforma Climática Latinoamericana: Quito, Ecuador, 2012. 
111. Di Paola, M.M.; Rivera, I. Informe Nacional Sobre el Estado y Calidad de las Políticas Públicas Sobre Cambio Climático y Desarrollo en Argentina: Sector Agropecuario y Forestal; Plataforma Climática Latinoamericana, Fundación Ambiente y Recursos Naturales: Buenos Aires, Argentina, 2012.

112. Bell, A.R.; Lemos, M.C.; Scavia, D. Cattle, Clean Water, and Climate Change: Policy Choices for the Brazilian Agricultural Frontier. Environ. Sci. Technol. 2010, 44, 8377-8384. [CrossRef] [PubMed]

113. Bäckstrand, K.; Lövbrand, E. Climate Governance after Copenhagen: Research Trends and Policy Practice. Research Handbook on Climate Governance; Edward Elgar Publishing: Cheltenham Glos, UK, 2015.

114. Feola, G. Societal transformation in response to global environmental change: A review of emerging concepts. Ambio 2015, 44, 376-390. [CrossRef] [PubMed]

115. Postigo, J.C.; Chacón Cancino, P.; Geary, M.; Blanco Wells, G.; Fuenzalida, M.I.; de la Cuadra, F.; Lampis, A.; Malvares Miguez, M.; Palacio, G.; Torres Martínez, J.; et al. Cambio Climático, Movimientos Sociales y Políticas Públicas: Una Vinculación Necesaria; Consejo Latinoamericano de Ciencias Sociales, Instituto de Ciencias Alejandro Lipschutz (ICAL, Chile): Santiago, Chile, 2013.

116. Linnér, B.-O.; Mickwitz, P.; Román, M. Reducing greenhouse gas emissions through development policies: A framework for analysing policy interventions. Clim. Dev. 2012, 4, 175-186. [CrossRef]

117. Mbatu, R.S. REDD+ research: Reviewing the literature, limitations and ways forward. For. Policy Econ. 2016, 73, 140-152. [CrossRef]

118. Likens, G.E. The role of science in decision making: Does evidence-based science drive environmental policy? Front. Ecol. Environ. 2010, 8, 1-9. [CrossRef]

119. Cáceres, D.M.; Silvetti, F.; Díaz, S. The rocky path from policy-relevant science to policy implementation-A case study from the South American Chaco. Curr. Opin. Environ. Sustain. 2016, 19, 57-66. [CrossRef]

(C) 2017 by the authors. Licensee MDPI, Basel, Switzerland. This article is an open access article distributed under the terms and conditions of the Creative Commons Attribution (CC BY) license (http://creativecommons.org/licenses/by/4.0/). 